\title{
PEMBELAJARAN DENGAN PENDEKATAN KONTEKSTUAL BERBANTUAN SOFTWARE FOCUSKY UNTUK MENINGKATKAN KEMAMPUAN BERPIKIR KRITIS DAN DISPOSISI MATEMATIS
}

\author{
LEARNING WITH CONTEXTUAL APPROACH USING FOCUSKY SOFTWARE TO \\ INCREASE ABILITY OF CRITICAL THINKING AND MATHEMATIC DISPOSITION
}

\author{
I. Najmul, E. Cahya, \& N. Nurjanah \\ Universitas Pendidikan Indonesia, Indonesia \\ Irvanmutaqin90@gmail.com
}

\begin{abstract}
Penelitian ini bertujuan untuk mengkaji peningkatan kemampuan berpikir kritis dan disposisi matematis siswa SMA melalui pembelajaran dengan pendekatan kontekstual berbantuan software focusky. Desain penelitian yang digunakan adalah kuasi eksperimen. Populasi dalam penelitian ini adalah seluruh siswa kelas X di salah satu SMA di Kabupaten Karawang. Instrumen yang digunakan dalam penelitian ini adalah pretes dan postes untuk kemampuan berpikir kritis dan disposisi matematis. Hasil penelitian dianalisis dengan menggunakan Microsoft Excel 2013 dan SPSS versi 21. Hasil penelitian menunjukkan bahwa: 1) Peningkatan kemampuan berpikir kritis siswa yang memperoleh pembelajaran dengan pendekatan kontekstual berbantuan software focusky secara keseluruhan lebih baik daripada siswa yang memperoleh pembelajaran dengan pendekatan kontekstual 2) disposisi matematis siswa yang memperoleh pembelajaran dengan pendekatan kontekstual berbantuan software focusky tidak lebih baik daripada siswa yang memperoleh pembelajaran dengan pendekatan kontekstual.
\end{abstract}

Kata Kunci: Pembelajaran, Software Focusky, Kemampuan Berpikir

\section{ABSTRACT}

This study aims to examine the improvement of critical thinking skills and mathematical disposition of high school students through learning with contextual-assisted focusky software approach. The research design used was quasi experiment. Population in this research is all student of class X in one of SMA in Kabupaten Karawang. The instruments used in this study are pretest and postes for critical thinking skills and mathematical dispositions. The results of the study were analyzed using Microsoft Excel 2013 and SPSS version 21. The results showed that: 1) Improvement of critical thinking skills of students who acquired learning with contextual approach with focusky software assistance overall better than students who received learning with contextual approach 2) mathematical disposition students who received learning with contextually-focused approaches focusky software were no better than students who obtained learning with a contextual approach.

Keywords: Learning, Focusky Software, Thinking Ability

\section{PENDAHULUAN}

Departemen Pendidikan Nasional memberi penekanan yang serius terhadap pendidikan matematika diberbagai tingkat pendidikan, sejak sekolah dasar (SD) sampai universitas. Walaupun peradaban manusia berubah dengan pesat, namun bidang matematika terus relevan dan menunjang pada perubahan. Matematika merupakan ilmu universal yang melandasi perkembangan teknologi modern, mempunyai peranan penting dalam berbagai disiplin ilmu dan pengembangan daya pikir manusia. Matematika merupakan pembelajaran yang sangat penting di dalam sistem pendidikan di seluruh negara di dunia ini. Negara yang mengabaikan pembelajaran matematika sebagai prioritas utama akan tertinggal dari segala bidang (terutama sains dan teknologi), dibanding dengan negaranegara lainnya yang memberikan tempat bagi matematika sebagai subjek yang sangat penting (Masykur \& Fathani, 2009).

Peraturan Mendiknas No. 23 tahun 2006 tentang standar kelulusan siswa salah satunya disebutkan bahwa untuk pelajaran matematika di SMA standar yang diharapkan 
adalah siswa menunjukkan kemampuan berpikir logis, kritis, kreatif dan inovatif, menunjukkan kemampuan belajar secara mandiri sesuai potensi yang dimilikinya dan menunjukkan kemampuan menganalisis dan memecahkan masalah dalam kehidupan sehari-hari. Pentingnya berpikir dalam proses belajar matematika adalah karena dalam proses belajar matematika siswa dituntut untuk melakukan kegiatan mental, dengan berpikir siswa akan mampu menyusun hubungan-hubungan informasi yang direkam oleh siswa sebagai pengertian-pengertian, dari pengertian-pengertian tersebutlah akan terbentuk pendapat yang pada akhirnya akan dapat ditarik kesimpulan. Selama proses pembelajaran matematika siswa sering sekali dihadapkan pada soal yang tidak dengan segera dapat diselesaikan artinya siswa harus berpikir dan bernalar terlebih dahulu, mencoba-coba, menaksir, menggunakan rumus-rumus sederhana dan kemudian baru membuktikannya, karena itu siswa perlu memilki keterampilan berpikir, yakni kemampuan berpikir kritis.

Glazer (Sabandar, 2009) menyatakan bahwa berpikir kritis adalah kemampuan dan disposisi yang melibatkan pengetahuan sebelumnya, penalaran matematis, dan strategi kognitif untuk mengeneralisasi, membuktikan maupun mengevaluasi situasi matematis dengan cara reflektif. Sejalan dengan Glazer (Syahbana, 2012) mengemukakan bahwa kemampuan berpikir kritis matematis adalah kemampuan mengidentifikasi dan menerapkan konsep, menggeneralisasi atau menghubungkan, menganalisis algoritma, dan memecahkan masalah matematis. Selain itu, menurut Ennis (Helmi, 2010), kemampuan berpikir kritis meliputi lima aktivitas, yaitu memberikan penjelasan sederhana, membangun keterampilan dasar, menarik kesimpulan, memberikan penjelasan lebih lanjut, dan membuat strategi dan teknik.

Meningkatkan kemampuan berpikir kritis matematis sangat penting dilakukan. Menurut (Fachrurazi, 2011), di era globalisasi saat ini, kemampuan berpikir kritis sangat diperlukan agar siswa sanggup menghadapi perubahan keadaan atau tantangan yang terjadi dalam kehidupan sehari-hari. Dengan mengembangkan kemampuan berpikir kritis matematis dalam pembelajaran matematika, siswa dapat berpartisipasi secara aktif untuk memperoleh dan merasakan pengalamanpengalaman yang bermakna dalam proses pembelajaran, di mana pengalaman tersebut akan memperkuat hubungan antara pengetahuan yang baru mereka peroleh dengan pengetahuan mereka sebelumnya.

Kenyataan di lapangan memang menunjukkan bahwa siswa mengalami kesulitan dan hambatan dalam mengembangkan kemampuan berpikir kritis matematis. Upaya pengembangan kemampuan berpikir kritis matematis masih jarang dilakukan serta kurang diperhatikan dalam pembelajaran matematika. Hasil pengamatan peneliti terhadap siswa kelas XI di salah satu SMA Negeri di Kabupaten Karawang, kecenderungan siswa menganggap bahwa matematika adalah pelajaran yang sulit untuk dipelajari dan jika diperbolehkan mereka berusaha menghindar dari bidang studi matematika. Tingkat kemampuan komunikasi dan berpikir kritis matematis siswa terlihat masih kurang, hal tersebut ditemukan peneliti setelah melakukan observasi dengan memberikan butir tes komunikasi matematis dengan indikator kemampuan "mengemukakan suatu ide atau 
situasi matematis ke dalam bentuk gambar, menyatakan suatu situasi atau ide matematis ke dalam bentuk simbol atau model matematis dan menyelesaikannya, menuliskan ide atau situasi matematis yang diberikan dengan bahasa sendiri, dan menyatakan suatu gambar atau model matematis ke dalam bentuk ide matematis."

Pembelajaran matematika tidak hanya dimaksudkan untuk mengembangkan aspek kognitif, tetapi juga untuk mengembangkan aspek afektif, seperti disposisi matematis. Disposisi berkaitan dengan kecenderungan siswa untuk merefleksi pemikiran mereka sendiri. Disposisi siswa terhadap matematika tampak ketika, apakah dikerjakan dengan percaya diri, tanggung jawab, tekun, pantang putus asa, merasa tertantang, memiliki kemauan untuk mencari cara lain dan melakukan refleksi terhadap cara berpikir yang telah dilakukan.

Unsur sikap yang dikaji dalam penelitian ini adalah disposisi matematis siswa. Menurut (Wardani, Sumarmo, \& Nishitani, 2011) disposisi matematis adalah ketertarikan dan apresiasi terhadap matematika yaitu kecenderungan untuk berpikir dan bertindak dengan positif, termasuk kepercayaan diri, keingintahuan, ketekunan, antusias dalam belajar, gigih mengahadapi permasalahan, fleksibel, mau berbagi dengan orang lain, reflektif dalam kegiatan matematik. Jadi disposisi matematis adalah keinginan, kesadaran, dan dedikasi yang kuat pada diri siswa untuk belajar matematika dan melaksanakan berbagai kegiatan matematika.

Disposisi matematis merupakan salah satu faktor penunjang keberhasilan belajar matematika siswa. Siswa diharapkan memiliki disposisi yang tinggi dalam menghadapi masalah, mengambil tanggung jawab, dan mengembangkan kebiasaan kerja yang baik dalam belajar matematika. Oleh karena itu, disposisi matematis siswa harus dikembangkan sejak dini. Kelak, siswa belum tentu dapat memanfaatkan semua materi matematika yang telah dipelajarinya. Namun, dapat dipastikan bahwa mereka memerlukan disposisi positif untuk mengahadapi situasi problematis dalam kehidupan mereka.

Seorang guru dituntut untuk dapat memilih model pembelajaran yang tepat. Banyak model pembelajaran yang sudah dikembangkan oleh guru untuk meningkatkan peran aktif peserta didik. (Ruseffendi, 2006) menyatakan bahwa pendekatan merupakan suatu jalan, cara atau kebijaksaan yang ditempuh oleh guru atau siswa dalam mencapai tujuan pengajaran dilihat dari sudut bagaimana proses pengajaran atau materi pelajaran itu dikelola. Salah satu alternatif pendekatan pembelajaran matematika yang diperkirakan dapat meningkatkan kemampuan berpikir kritis, dan disposisi matematis siswa adalah pendekatan kontekstual.

Menurut (Sanjaya, 2011) pendekatan kontekstual adalah suatu strategi pembelajaran yang menekankan proses keterlibatan siswa secara penuh untuk dapat menemukan materi yang dipelajari dan menghubungkannya dengan situasi kehidupan nyata sehingga mendorong siswa untuk dapat menerapkannya dalam kehidupan mereka. Melalui penerapan materi dalam kehidupan sehari-hari, siswa akan merasakan pentingnya belajar dan akan memperoleh makna yang mendalam terhadap apa yang dipelajarinya sehingga materi tersebut akan tertanam erat dalam memori siswa.

Berdasarkan uaraian tersebut, peneliti bermaksud melakukan penelitian tentang "Pembelajaran dengan Pendekatan 
Kontekstual Berbantuan Software Fokusky untuk Meningkatkan Kemampuan Berpikir Kritis dan Disposisi Matematis pada Siswa SMA".

\section{METODE PENELITIAN}

Penelitian ini merupakan penelitian kuasi eksperimen karena pada penelitian ini subjek tidak dikelompokkan secara acak, tetapi peneliti menerima keadaan subjek apa adanya (Ruseffendi, 2006). Desain penelitian yang digunakan untuk aspek kognitif, yaitu kemampuan komunikasi dan berpikir kritis matematis adalah nonequivalent control group design (Sugiyono, 2010). Pengambilan sampel dilakukan dengan teknik purposive sampling, karena sampel dikelompokkan secara tidak acak, tetapi peneliti menerima keadaan sampel apa adanya dan kelas yang ada telah terbentuk sebelumnya.

Untuk memperoleh data dalam penelitian ini, digunakan dua jenis instrumen, yaitu tes dan non-tes. Instrumen dalam bentuk tes terdiri dari seperangkat soal tes untuk mengukur kemampuan kemampuan berpikir kritis matematis. Sedangkan instrumen dalam bentuk non tes yaitu berupa skala disposisi matematis siswa, lembar observasi selama kegiatan berlangsung dan bahan ajar.

Tes kemampuan berpikir kritis matematis dilakukan saat pre-test dan post-test pada kelas eksperimen berbantuan software focusky dan kelas eksperimen, tahapannya yaitu menentukan skor jawaban siswa sesuai dengan kunci jawaban dengan rumus gain ternormalisasi. Kemudian melakukan uji normalitas dan homogenitas. Setelah data memenuhi syarat normal dan homogen, selanjutnya dilakukan uji kesamaan rataan skor pretes dan uji perbedaan rataan skor postes dan gain menggunakan uji-t yaitu Independent Sample T-Test.

\section{HASIL DAN PEMBAHASAN}

Analisis data peningkatan kemampuan berpikir kritis siswa menggunakan data gain ternormalisasi (N-gain). Uji normalitas data $\mathrm{N}$-gain dilakukan menggunakan uji statistik Shapiro-Wilk dengan taraf signifikansi 0,05.

Tabel 1

Data Hasil Uji Normalitas Skor N-gain Kemampuan Berpikir Kritis

\begin{tabular}{|c|c|c|c|}
\hline \multirow[b]{2}{*}{ Kelas } & \multicolumn{2}{|c|}{ Shapiro-Wilk } & \multirow[b]{2}{*}{ Keputusan } \\
\hline & $\mathrm{df}$ & Sig. & \\
\hline Eksperimen 1 & 40 & 0,406 & Terima $H_{0}$ \\
\hline Eksperimen 2 & 40 & 0,533 & Terima $H_{0}$ \\
\hline
\end{tabular}

Berdasarkan Tabel 1, terlihat nilai signifikansi (sig.) uji Shapiro-Wilk skor $\mathrm{N}$-gain kelas eksperimen satu yaitu 0,406 lebih besar dari $\alpha=0,05$. Dengan demikian $H_{0}$ diterima artinya pada taraf signifikansi 5\% data $\mathrm{N}$-gain kemampuan berpikir kritis kelompok eksperimen satu berdistribusi normal. Selanjutnya nilai signifikansi (sig.) uji Shapiro-Wilk skor N-gain kelas eksperimen dua yaitu 0,533 lebih besar dari $\alpha=0,05$. Dengan demikian $H_{0}$ diterima artinya pada taraf signifikansi $5 \%$ data $\mathrm{N}$-gain kemampuan berpikir kritis kelompok eksperimen dua berdistribusi normal. Setelah skor N-gain untuk kedua kelas memenuhi syarat kenormalan, maka selanjutnya dilakukan uji homogenitas. 
Tabel 2

Data Hasil Uji Homogenitas Skor N-Gain Kemampuan Berpikir kritis

\begin{tabular}{ccccc}
\hline Levene Statistic & df1 & df2 & Sig. & Keputusan \\
\hline 1,579 & 1 & 78 & 0,213 & Terima $H_{0}$ \\
\hline
\end{tabular}

Berdasarkan tabel 2 terlihat bahwa sig. untuk kedua kelas lebih besar dari 0,05 yaitu 0,213 sehingga keputusannya $H_{0}$ diterima. Hal ini berarti varians populasi data N-Gain kemampuan berpikir kritis

Tabel 3

Data Hasil Uji Independent Sampel t-test Data N-Gain Kemampuan Berpikir Kritis

\begin{tabular}{|c|c|c|c|c|}
\hline \multirow[t]{2}{*}{ Hasil } & \multicolumn{3}{|c|}{ t-test for Equality of Means } & \multirow[t]{2}{*}{ Keputusan } \\
\hline & $\mathrm{t}$ & Df & Sig.(1-tailed) & \\
\hline $\begin{array}{l}\text { N-Gain Kemampuan Berpikir } \\
\text { Kritis }\end{array}$ & 4,584 & 78 & 0,000 & Tolak $H_{0}$ \\
\hline
\end{tabular}

Berdasarkan Tabel 3 di atas, diperoleh nilai Sig.(1-tailed) adalah 0,000 lebih kecil dari taraf signifikansi $\alpha=0,05$. Keputusan yang diambil adalah $H_{0}$ ditolak. Dengan demikian dapat disimpulkan bahwa Peningkatan kemampuan berpikir kritis siswa yang memperoleh pembelajaran dengan pendekatan kontekstual berbantuan software focusky secara signifikan lebih baik daripada siswa yang memperoleh pembelajaran dengan pendekatan kontekstual.

Hal ini sesuai dengan temuan (Herlina, Turmudi, \& Dahlan, 2012) bahwa kerja sama dalam kelompok sebagai usaha untuksharing-

Tabel 4

Data Hasil Uji Normalitas Skor Disposisi Matematis

\begin{tabular}{lccc}
\hline \multirow{2}{*}{ Kelas } & \multicolumn{2}{c}{ Shapiro-Wilk } & \multirow{2}{*}{ Keputusan } \\
\cline { 2 - 3 } Eksperimen 1 & df & Sig. & Terima $H_{0}$ \\
\hline Eksperimen 2 & 40 & 0,893 & Terima $H_{0}$ \\
\hline
\end{tabular}

Terlihat pada tabel 4, nilai signifikansi (sig.) uji Shapiro-Wilk data skor memiliki nilai lebih besar dari $\alpha=0,05$. Dengan demikian $H_{0}$ diterima, artinya pada taraf signifikansi 5\% data skor disposisi matematis responding-communicating yang efektif dapat mengembangkan berpikir analitik dan kritis. Dibantu dengan tampilan software focusky untuk membantu siswa dalam visualisasi materi ruang dimensi tiga. Peran teknologi dan media dalam pembelajaran geometri terletak dalam visualisasi.

Hasil skala sikap disposisi matematis telah dikonversi dalam bentuk interval dengan menggunakan Method of Succesive Interval (MSI). Uji Normalitas data dilakukan menggunakan uji statistik Shapiro-Wilk dengan taraf signifikansi 0,05 . 
digunakan uji tes Levene Statistic dengan taraf signifikansi 0,05.

Tabel 5

Data Hasil Uji Homogenitas Skor Disposisi Matematis

\begin{tabular}{ccccc}
\hline Levene Statistic & df1 & df2 & Sig. & Keputusan \\
\hline 1,340 & 1 & 78 & 0,251 & Terima $H_{0}$ \\
\hline
\end{tabular}

Berdasarkan tabel 5 terlihat bahwa sig. untuk kedua kelas lebih besar dari 0,05 yaitu 0,251 sehingga keputusannya $H_{0}$ diterima. Hal ini berarti varians populasi data skor disposisi matematis kelas eksperimen satu dan eksperimen dua homogen.

Setelah mengetahui data skor disposisi matematis memenuhi syarat kenormalan dan homogenitas, maka dilanjutkan dengan uji perbedaan rataan dengan menggunakan uji Independent Sampel t-test dengan taraf signifikansi 0,05 .

Tabel 6

Data Hasil Uji Independent Sampel t-test Data Skor Disposisi Matematis

\begin{tabular}{|c|c|c|c|c|}
\hline \multirow[t]{2}{*}{ Hasil } & \multicolumn{3}{|c|}{ t-test for Equality of Means } & \multirow[t]{2}{*}{ Keputusan } \\
\hline & $\mathrm{t}$ & Df & Sig.(2-tailed) & \\
\hline Skor disposisi matematis & -1.472 & 78 & 0,145 & Terima $H_{0}$ \\
\hline
\end{tabular}

Berdasarkan Tabel 6 di atas, diperoleh nilai Sig.(1-tailed) adalah 0,072 lebih besar dari taraf signifikansi $\alpha=0,05$. Keputusan yang diambil adalah $H_{0}$ ditolak. Hal ini berarti disposisi matematis siswa kelas eksperimen satu yang memperoleh pendekatan kontekstual berbantuan software focusky secara signifikan tidak lebih baik daripada siswa kelas eksperimen dua yang memperoleh pembelajaran kontekstual.

Pembelajaran dengan pendekatan kontekstual berbantuan software focusky mempunyai beberapa keunggulan dalam mengembangkan disposisi matematis. Kesempatan siswa mengemukakan pendapat dan diskusi lebih banyak sehingga memungkinkan timbulnya rasa percaya diri siswa. tampilan software focusky yang menarik menimbulkan gairah, perhatian, rasa ingin tahu, dan motivasi belajar. Hal ini didukung oleh Atallah (2010) bahwa motivasi sangat berhubungan erat dengan disposisi. Selain itu volume yang lebih banyak pada saat berkolaborasi mendeteksi kesalahan dan mereview memungkinkan siswa lebih fleksibel dan menghargai pendapat rekannya. Demikian juga pembelajaran dengan pendekatan kontekstual berbantuan software focusky memotivasi siswa untuk gigih menghadapi dan menyelesaikan masalah. Selain itu siswa menjadi lebih tertantang untuk belajar dan memanfaatkan kelompok sebagai wadah mencari ilmu dan bertukar informasi. (Danoebroto, 2015) mengatakan bahwa interaksi sosial dalam pembelajaran sesuai teori Vygotsky tidak hanya potensial bagi terbangunnya pengetahuan matematika pada diri siswa tetapi juga potensial dalam membangun kemampuan berpkir matematis dan sikap positif siswa terhadap matematika.

\section{SIMPULAN}

Berdasarkan hasil penelitian serta pembahasan yang telah diuraikan a diperoleh kesimpulan hasil-hasil penelitian sebagai berikut: 1). Peningkatan kemampuan berpikir kritis siswa yang memperoleh pembelajaran dengan pendekatan kontekstual berbantuan Jurnal Penelitian Pendidikan 
software focusky lebih baik daripada siswa yang memperoleh pembelajaran dengan pendekatan kontekstual 2). Disposisi matematis siswa yang menerapkan pembelajaran dengan pendekatan kontekstual berbantuan software focusky secara signifikan tidak lebih baik daripada siswa yang mendapat pembelajaran dengan pendekatan kontekstual.

\section{DAFTAR RUJUKAN}

Danoebroto, S. W. (2015). Teori belajar konstruktivis Piaget dan Vygotsky. Indonesian Digital Journal of Mathematics and Education, 2(3), 191-198.

Fachrurazi. (2011). Penerapan Pembelajaran Berbasis Masalah untuk Meningkatkan Kemampuan Berpikir Kritis dan Komunikasi Matematis Siswa SD. Jurnal Penelitian Pendidikan, (1), 76-89.

Helmi. (2010). Memahami Berpikir Kritis. Retrieved from http://helm.student.umm.ac.id/2010/08/12/memahamiberpikir-kritis/html

Herlina, S., Turmudi, \& Dahlan, J. . (2012). Efektivitas strategi REACT dalam upaya peningkatan kemampuan komunikasi matematis siswa sekolah menengah pertama. Jurnal Pengajaran MIPA, 17(1), 1-7.

Masykur, M., \& Fathani, A. H. (2009). Mathematical Intelligence (Cara Cerdas Melatih Otak dan Menanggulangi Kesulitan Belajar). Yogyakarta: Ar-ruzz Media.

Ruseffendi, E. T. (2006). Pengantar kepada membantu guru mengembangkan kompetensinya dalam pengajaran matematika untuk meningkatkan CBSA. Bandung: Tarsito.

Sabandar, J. (2009). Thinking Classroom dalam Pembelajaran Matematika di Sekolah. Jurnal Pendidikan Matematika.

Sanjaya, W. (2011). Strategi Pembelajaran Berorientasi Standar Proses Pendidikan. Jakarta: Kencana Prenada Media.

Sugiyono. (2010). Metode Penelitian Pendidikan. Bandung: Alfabeta.

Syahbana, A. (2012). Peningkatan Kemampuan Berpikir Kritis Matematis Siswa SMP melalui Pendekatan Contextual Teaching and Learning. Jurnal Nasional Edumatica, 2(1), 45-57.

Wardani, S., Sumarmo, U., \& Nishitani, I. (2011). Mathematical Creativity and Disposition: Experiment With Grade-10 Students using Silver Inquiry Approach. Journal of Science and Mathematics Teaching, GUNMA University, 1-16. 